\title{
Żydowskie egodokumenty w serii „Żydzi. Polska. Autobiografia”
}

Od kilku dekad w obszarze badań historycznych i literaturoznawczych obserwujemy nieustający wzrost zainteresowania egodokumentami. Samo pojęcie zostało wprowadzone jako neologizm we wczesnych latach pięćdziesiątych przez holenderskiego historyka o żydowskim pochodzeniu Jacques'a Pressera (1899-1970), dziś rozpoznawanego przede wszystkim dzięki pracom poświęconym Zagładzie Żydów w Holandii. Egodokumenty definiował on jako: “Te źródła historyczne, w których użytkownik jest konfrontowany z »ja« lub czasami (Cezar, Henry Adams) z »on«, stale obecnym w tekście jako piszący i opisujący podmiot" . Trzeba zaznaczyć, że Presser propagował sięganie w badaniach historycznych do dokumentów osobistych w czasach, kiedy traktowane one były jako źródła małowartościowe ${ }^{2}$. Dziś do egodokumentów zaliczamy dzienniki, wspomnienia, pamiętniki, korespondencję osobistą. Na gruncie polskim często stosuje się nazwę „pisma autobiograficzne”, ponieważ pojęcie egodokumentu z opóźnieniem i pewnym oporem przedostaje się do polskiej humanistyki, choć niewątpliwie tego typu teksty są szeroko wykorzystywane.

Mimo iż stały się one jednym z najważniejszych źródeł w interdyscyplinarnych badaniach historyczno-społecznych, kulturowych czy literaturoznawczych, żydowska literatura wspomnieniowa jest niemal nieznana polskiemu czytelnikowi, i to nie tylko w kręgach popularnych, ale również

${ }^{1}$ Jacques Presser, Clio kijkt door het sleutelgat, [w:] tenże, Uit het werk van J. Presser, Amsterdam 1969, cyt. za: Rudolf Dekker, Introduction, [w:] Egodocuments and History: Autobiographical Writing in Its Social Context since the Middle Ages, red. Rudolf Dekker, Hilversum 2002, s. 7.

2 Tamże, s. 9. 
akademickich. Dzieje się tak ze względu na słabą dostępność części ważnych tekstów, odmienność kulturową utrudniającą ich zrozumienie, a przede wszystkim barierę językową. Aby w szerokim zakresie sięgać do żydowskich egodokumentów z ziem polskich, trzeba bowiem poza językiem polskim posiadać znajomość języków: hebrajskiego, jidysz, niemieckiego i rosyjskiego.

Sytuację tę może zmienić realizowany od 2017 r. w Katedrze Judaistyki im. Tadeusza Taubego na Uniwersytecie Wrocławskim projekt „Kanon literatury wspomnieniowej Żydów polskich”. Jego celem jest wprowadzenie żydowskiej literatury wspomnieniowej do polskiego obiegu naukowego i literackiego oraz zintegrowanie tego korpusu z obecną wiedzą na temat polskiej historii i kultury. Partnerami Katedry Judaistyki w tym przedsięwzięciu, sfinansowanym przez Ministerstwo Nauki i Szkolnictwa Wyższego w ramach Narodowego Programu Rozwoju Humanistyki, są Muzeum Historii Żydów Polskich POLIN oraz Wydawnictwo Naukowe PWN.

W roku 2018 w ramach projektu powstała seria wydawnicza „Żydzi. Polska. Autobiografia”, w której do 2023 r. ma się ukazać 27 krytycznie opracowanych tomów zawierających żydowską literaturę autobiograficzną powstałą od XVII do połowy wieku XX na ziemiach polskich (definiowanych tu szeroko - jako obszar dawnej Rzeczypospolitej Obojga Narodów). Głównym kryterium przyjętym przy doborze dzieł przeznaczonych do publikacji było jak największe zróżnicowanie kulturowe, językowe, społeczne oraz regionalne ich autorów. Tę różnorodność obrazuje wielość języków, z których thumaczone są tomy wydawane w omawianej serii. Są to przekłady z hebrajskiego, jidysz, niemieckiego, rosyjskiego oraz teksty powstałe po polsku. Wybrane do serii dzieła obejmują nie tylko wszystkie języki używane przez Żydów polskich i zamieszkałe przez nich regiony (centralna Polska, Małopolska, tereny dzisiejszej Ukrainy, Białorusi i Litwy), ale też różne grupy kulturowe, religijne czy polityczne.

Autorzy reprezentują rozmaite warstwy społeczne, osoby o różnym typie i stopniu wykształcenia, religijności i osadzenia w tradycyjnej kulturze żydowskiej. Są to mieszkańcy wielkich miast i małych miasteczek, osoby znane lub niewyróżniające się niczym szczególnym, ale w swoich wspomnieniach dostarczające wielu ważnych informacji z zakresu obyczajowości i historii życia codziennego, a niekiedy bezcennych wiadomości o wielkich wydarzeniach historycznych, w których przyszło im uczestniczyć. Z osób, które już za życia cieszyły się sławą i których wspomnienia zostaną wydane, można wymienić np. rozpoznawalnych dla polskiego czytelnika: Icchoka 
Lejbusza Pereca i Szaloma Abramowicza (czyli Mendelego Mojcher-Sforima) czy Szymona An-skiego. Ponadto jako piąty tom serii ukazały się już pamiętniki „matki teatru żydowskiego” Estery Racheli Kamińskiej; tom szósty to wspomnienia słynnego maskila Mordechaja Arona Gincburga; opublikowany również zostanie dziennik Sary Szenirer, uznanej reformatorki systemu kształcenia ortodoksyjnych Żydówek. W kanonie znalazły się też osoby zupełnie nieznane, np. czwarty tom serii zawiera wspomnienia Meira ben Jechiela Kadosza, który jako młodzieniec wędrował z Moraw do Polski, aby studiować w krakowskiej jesziwie, i w grudniu 1608 r. został porwany przez polskiego szlachcica, po czym przez długie tygodnie był więziony na dworze w Czechowicach. W opracowaniu redakcyjnym jest też autobiografia Beniamina R. - młodego chłopaka z Bielska Podlaskiego, wprowadzającego nas w świat partii politycznych, w których działalność angażowała się młodzież żydowska w latach trzydziestych XX w. Dobór pamiętników zaplanowanych do edycji ma zapewnić serii jako całości reprezentatywność uwzględniającą różnorodność doświadczeń i postaw.

Przy wyborze tekstów do wydania szczególnie ważne było dostrzeżenie pamiętników i dzienników pisanych przez kobiety. Ich obecność w kanonie nie koresponduje bowiem z faktem słabej reprezentatywności perspektywy kobiecej w dostępnych polskiemu odbiorcy egodokumentach żydowskich. Ten znacznie głębszy problem Laura Marcus - badaczka dyskursu o literaturze autobiograficznej - definiuje w następujący sposób:

Autobiografia była centralnym problemem krytyki feministycznej w latach osiemdziesiątych, która ujawniała procesy wykluczenia i marginalizacji w konstrukcji kanonów literackich. Nie tylko kobiety-autobiograficzki w oczywisty sposób pozostawały poza tradycją „Wielkich Mężczyzn”, w której obszarze działało wielu krytyków pracujących z tekstami autobiograficznymi, ale także definicje ogólne służyły wykluczeniu [kobiet] $]^{3}$.

Już przytoczona na wstępie, stworzona przez Pressera definicja egodokumentu, w której pojawia się uniwersalne „on” bez wariantu „ona”, unaocznia androcentryczność tradycji autobiograficznej ${ }^{4}$ W serii „Żydzi. Polska. Autobiografia" ukaże się dziewięć tomów, których teksty napisały

${ }^{3}$ Laura Marcus, Auto/biographical Discourses: Theory. Criticism. Practice, ManchesterNew York 1994, s. 1, tłum. cytatu - J. L.

${ }^{4}$ Refleksja badawcza nad tradycją autobiograficzną przez długi czas zdominowana była nie tylko przez perspektywę androcentryczną, ale także przez chrześcijańskocentryzm, por.: Joanna Lisek, W lustrze pamięci - problemy żydowskiej literatury autobiograficznej, „Autobiografia. Literatura. Kultura. Media” (2017), nr 1, s. 7-21. 
kobiety (Paulina Wengeroff, Sara Szenirer, Adela von Mieses, Estera Rachela Kamińska, Kadia Mołodowska, Malka Lee, Rachela Fajgenberg, Hinda Bergner, Pua Rakowska). Jest to o tyle ważne, że historia kobiet bardzo często nie jest reprezentowana w dokumentach archiwalnych i to właśnie literatura autobiograficzna pozwala odtworzyć w dużej mierze zapomniany świat różnorakiej aktywności Żydówek na terenach Polski. Kobiece autobiografie, dzienniki, pamiętniki, które zostaną wprowadzone do polskiego obiegu czytelniczego, mogą poszerzyć nasze wyobrażenia o funkcjonowaniu sztetla, o tworzeniu się kobiecych organizacji żydowskich, wprowadzić cenne elementy etnograficzne, pokazać drogę awansu społecznego Żydówek i strategie emancypacyjne, a przede wszystkim przybliżyć proces konstruowania kobiecego ,ja” w żydowskich egodokumentach.

Poniżej prezentowane są fragmenty przetłumaczonych z jidysz autobiografii dwóch pisarek żydowskich: Racheli Fajgenberg i Kadii Mołodowskiej, które wkrótce ukażą się jako ósmy i dziewiąty tom serii.

Joanna Lisek Uniwersytet Wrocławski email: joanna.degler@gmail.com 